\title{
Prognostic value of troponin I after elective percutaneous coronary intervention
}

\author{
Luis Alberto Arboine-Aguirre, José Eduardo Galván-García, Juan Manuel Palacios-Rodríguez and \\ Denisse Guzmán-Ramírez \\ Instituto Mexicano del Seguro Social, High Specialty Medical Unit 34, Cardiology Hospital, Monterrey, Nuevo León, Mexico
}

\begin{abstract}
Introduction: The significance of troponin I (Tn-I) elevation after percutaneous coronary intervention (PCI) is the subject of debate. Objective: To determine cardiovascular prognosis associated with Tn-I elevation one year after successful elective $\mathrm{PCl}$. Methods: Observational, retrospective, longitudinal study. Patients who underwent successful elective $P C l$ were included and divided in two groups: with and without Tn-l elevation, in order to compare the occurrence of major adverse cardiac events (MACE) at 1 year; post-PCI Tn-I was correlated with demographic and angiographic characteristics. Results: Tn-I elevation was detected in 32 patients (35.2\%). Elevation was more common in patients with multivascular and more complex coronary artery disease, and with peri-PCl complications. MACE incidence at one year was higher in the elevated Tn-l group (25\% vs. 3.4\%; $p=0.002$ ). Independent predictors of MACE were Tn-I 5-fold elevation from normal value (OR: 7.5; $95 \%$ Cl: 1.25-45; $p=0.027$ ) and peri- $\mathrm{PCl}$ complications (OR: $7.5 ; 95 \% \mathrm{Cl}: 1.25-45 ; p=0.027$ ). Conclusions: In patients with stable coronary artery disease, Tn-l elevation after successful elective $\mathrm{PCl}$ is associated with adverse cardiac events at 1 year, more extensive and complex coronary artery disease and peri-PCl complications.
\end{abstract}

KEY WORDS: Troponin I. Percutaneous coronary intervention. Major adverse cardiovascular events.

\section{Introduction}

Acute coronary syndromes are an important cause of morbidity and mortality in the world. ${ }^{1}$ In Mexico, they are the number one cause of death in subjects older than 60 years ${ }^{2,3}$ and their prevalence is expected to increase in next years. ${ }^{4}$ Percutaneous coronary intervention $(\mathrm{PCl})$ has become a widely used therapy that is effective in ischemic heart disease, with nearly 1.7 million procedures performed annually and an immediate success rate $>90 \% .{ }^{5}$ Severe complications are rare; ${ }^{6}$ however, small increases in troponin and creatine phosphokinase MB fraction (CPK-MB) levels are often found after elective coronary angioplasty in patients with a successful procedure. ${ }^{7,8}$ Troponin and CPK-MB elevation after coronary angioplasty has been documented to occur in 5 to $50 \%$ of patients. ${ }^{9,10}$
Although troponin I (Tn-I) importance and prognostic value in patients with acute coronary syndrome are clear, the prognostic significance of this biomarker elevation after elective percutaneous coronary intervention remains a subject of debate. Previous results on association of its elevation after elective $\mathrm{PCl}$ and cardiac events are not clear and ambiguous. ${ }^{11}$ Studies with magnetic resonance imaging have shown that even small increases in CPK-MB and troponin are associated with new irreversible myocardial damage and that, in addition, there is positive correlation between the magnitude of damage and troponin release extent. $^{12,13}$ This myocardial damage might cause cardiac function deterioration, affecting subsequent prognosis of patients..$^{14,15}$

The purpose of our study was to determine major adverse cardiac events (MACE) prognostic implication at one year, associated with a $\mathrm{Tn}-\mathrm{I}$ value increase
Correspondence:

Luis Alberto Arboine-Aguirre

E-mail: luisarboine1986@gmail.com
Date of reception: 07-03-2017

Date of acceptance: 06-02-2018

DOI://dx.doi.org/10.24875/GMM.M18000149
Gac Med Mex. 2018;154:261-266

Contents available at PubMed www.gacetamedicademexico.com 
above reference values after successful elective percutaneous coronary intervention.

\section{Method}

Patients of either gender, of any age, diagnosed with stable chronic angina, who had undergone elective percutaneous coronary intervention that was considered to be successful between May 14, 2013 and May 14, 2014, were included. Post-procedure myonecrosis biomarker levels were determined, with the sample being divided in two groups for analysis and comparison: patients with and without Tn-I elevation above the reference value. Clinical, demographic and angiographic variables were analyzed, as well as the presence of MACE, at one year of follow-up in both groups in order to compare them with each other. Patients with recent acute coronary syndrome (at less than 7 days) and with incomplete medical records were excluded from the study.

Coronary lesions were assessed during the procedure by means of coronary angiography with multiple orthogonal views. All angioplasties were carried out with standard techniques. Prior to $\mathrm{CPI}$, patients were treated with 150 to $300 \mathrm{mg}$ acetylsalicylic acid, and if the decision was made to place one or several stents, they received a clopidogrel loading dose of 300 to $600 \mathrm{mg}$ prior to implantation. During the CPI, patients were treated with $100 \mathrm{U} / \mathrm{kg}$ of intravenous heparin. The decision on radial versus femoral approach, stent placement, use of glycoprotein IIb/IIla (GP Ilb/Illa) inhibitors and intra-aortic balloon counterpulsation was left to the discretion of the interventional cardiologist. After the CPI, acetylsalicylic acid use was recommended indefinitely and clopidogrel for 3 to 12 months, depending on the type of implanted stent (medicated versus non-medicated). Angiographic lesions were classified according to American Heart Association/American College of Cardiology (AHA/ACC) criteria. A successful procedure was defined by a coronary artery residual stenosis $<30 \%$, with a thrombolysis in myocardial infarction (TIMI) grade 3 coronary flow, according to the American Heart Association/American College of Cardiology coronary intervention management guidelines.

Serum cardiac biomarker samples ( $\mathrm{Tn}-\mathrm{I}$ and CPK$M B)$ were obtained at 6 and 12 hours of the procedure. If the results were abnormal, subsequent samples were taken until peak level was established. Tn-I and CPK-MB serum values were determined by means of chemiluminescent microparticle immunoassay with Architect System $4100^{\circledR}$ (Abbot Diagnostics), with an
Table 1. Variables associated with post-procedure troponin I increase

\begin{tabular}{lcc|c}
\hline Variable & OR & Cl & p \\
\hline Bifurcation PCl & 3.33 & $1.1-9.4$ & 0.020 \\
Elevated CK-MB & 7.2 & $2.7-19.1$ & $<0.001$ \\
Peri-PCl complications & 9.7 & $2.4-38.5$ & $<0.001$ \\
23 to 32-point syntax & 4.0 & $1.3-12.4$ & -0.012 \\
\hline Cl=confidence interval, CPK-MB=creatine phosphokinase MB, OR=odds ratio, & \\
PCl=percutaneous coronary intervention. & &
\end{tabular}

upper limit of normal (ULN) of $0.40 \mathrm{ng} / \mathrm{mL}$ for TN-I and $24 \mathrm{U} / \mathrm{L}$ for CPK-MB.

Data were obtained by means of telephone interviews to patients and their families and by means of electronic medical records review. A standardized form was used to document MACEs: death, acute myocardial infarction, new $\mathrm{PCl}$ and myocardial revascularization surgery.

Non-categorical variables were expressed with central tendency measures (mean) and dispersion measures (standard deviation), whereas categorical variables were expressed using simple and relative frequency. Tn-I highest post-CPI value was used for analysis. Categorical variables comparisons were made using the chi-square test, whereas non-categorical variables were compared with Mann-Whitney $\mathrm{U}$-test owing to asymmetric distribution of the sample. Univariate analysis was carried out with the chi-square test to assess clinical-demographic, angiographic and procedure characteristics associated with $\mathrm{Tn}$-l elevation. A logistic regression multivariate analysis model was used to determine factors independently related to the incidence of major adverse cardiac events at one year of follow-up. A p-value $\leq 0.05$ was considered statistically significant for all analyses. The SPSS statistical program, version 22, was used.

\section{Results}

From May 13, 2013 to May 14, 2014, 91 patients met the selection criteria; 32 (35.2\%) had troponin elevation $(>0.40 \mathrm{ng} / \mathrm{mL})$, out of which $20(62.5 \%)$ had post-PCI CK-MB elevation as well (> $24 \mathrm{U} / \mathrm{L}) ; 59$ patients $(64.8 \%)$ showed no Tn-I elevation. Within the elevated $\mathrm{Tn}$-I group, 14 patients $(43.8 \%)$ had troponin levels more than $5 \times$ ULN. Categorical variables associated with post-PCl Tn-I elevation are shown in table 1.

Baseline demographic and clinical variables were similar in both groups, except for hospital length of stay, 
Table 2. Clinical-demographic characteristics of patients who underwent successful elective percutaneous coronary intervention

\begin{tabular}{|c|c|c|c|c|c|c|c|}
\hline \multirow[t]{2}{*}{ Variable } & \multicolumn{6}{|c|}{ Mean \pm SD } & \multirow[b]{2}{*}{$\stackrel{\infty}{-}$} \\
\hline & \multicolumn{2}{|c|}{ Total patients $(\mathrm{n}=91)$} & \multicolumn{2}{|c|}{ Elevated Tn-I $(n=32)$} & \multicolumn{2}{|c|}{ Tn-I no elevada $(n=59)$} & \\
\hline Age & \multicolumn{2}{|c|}{$60.43 \pm 10$} & \multicolumn{2}{|c|}{$61.41 \pm 10$} & \multicolumn{2}{|c|}{$59.90 \pm 11$} & \multirow{4}{*}{$\begin{array}{l}0.514 \\
<0.011 \\
<0.001 \\
\subset 0.001\end{array}$} \\
\hline Hospital length of stay & & & & & & & \\
\hline Tn-I peak & & & & & & & \\
\hline \multirow[t]{2}{*}{ CK-MB peak } & \multicolumn{2}{|c|}{$38.85 \pm 66.3$} & \multicolumn{2}{|c|}{$75.82 \pm 101.2$} & \multicolumn{2}{|c|}{$18.80 \pm 13.5$} & \\
\hline & $\mathrm{n}$ & $\%$ & $\mathrm{n}$ & $\%$ & $\mathrm{n}$ & $\%$ & \\
\hline Male gender & 66 & 72.5 & 21 & 65.6 & 45 & 76.3 & 0.277 \\
\hline Diabetes mellitus & 47 & 51.6 & 16 & 50.0 & 31 & 52.5 & 0.817 \\
\hline Systemic hypertension & 67 & 73.6 & 26 & 81.2 & 41 & 69.5 & 0.224 \\
\hline Dyslipidemia & 49 & 53.8 & 14 & 43.8 & 35 & 59.3 & 0.155 \\
\hline Smoking & 37 & 40.7 & 12 & 37.5 & 25 & 42.4 & 0.651 \\
\hline Previous AMI & 38 & 41.8 & 13 & 40.6 & 25 & 42.4 & 0.872 \\
\hline CCS angina class & & & & & & & $\stackrel{1}{2}$ \\
\hline I & 6 & 6.6 & 3 & 9.4 & 3 & 5.1 & $\frac{\subsetneq}{c} 0.431$ \\
\hline$\|$ & 59 & 64.8 & 21 & 65.6 & 38 & 64.4 & \pm 0.907 \\
\hline III & 19 & 20.9 & 5 & 15.6 & 14 & 23.7 & 0.364 \\
\hline IV & 7 & 7.7 & 3 & 9.4 & 4 & 6.8 & 0.657 \\
\hline Ischemia study & 83 & 91.2 & 31 & 96.9 & 52 & 88.1 & 0.160 \\
\hline EST & 34 & 41 & 10 & 32.3 & 24 & 46.2 & $=0.375$ \\
\hline MS & 36 & 43.4 & 17 & 54.8 & 19 & 36.5 & 0.510 \\
\hline DSE & 13 & 15.7 & 4 & 12.5 & 9 & 15.3 & 0.720 \\
\hline
\end{tabular}

$\mathrm{AMI}=$ acute myocardial infarction, CCS=Canadian Cardiovascular Society, CPK-MB=creatine phosphokinase MB, DSE=dobutamine stress echocardiogram, EST=exercise stress test, MS=myocardial scintigraphy, Tn-I=troponin I.

which was more prolonged in the elevated Tn-I group $(3.7 \pm 3.5$ versus $2 \pm 0.65$ days, $p=0.011)$ and $\mathrm{Tn}-\mathrm{I}$ and CPK-MB peak values (Table 2). The majority of patients $(83,91.2 \%)$ had an ischemia-inducing study prior to the procedure, most of them cardiac scintigraphy $(43.4 \%)$.

In the group with Tn-I elevation, angiographic and procedure variables (Table 3 ) revealed larger extension of coronary disease (number of affected vessels), as well as larger number of treated vessels and use of stents. In this group, more complex coronary disease was recorded, with higher Syntax score and more common coronary stenosis management in bifurcations. More frequency of complications was also found in the elevated Tn-I group (11 [34 \%] versus $3[5.1 \%], p=0.001)$. The most common complication in both groups was secondary branch occlusion in $50 \%$, followed by coronary dissection in $21.4 \%$.

\section{Major adverse cardiovascular events at 1 year}

During the 12-month follow-up, cardiac adverse events were documented in 10 patients (11\%), 8 in the elevated Tn-I group and 2 in the non-elevated Tn-I group ( $p=0.002)$; MACEs for each group are shown in figure 1. In the elevated Tn-I group, the univariate analysis showed that the MACE-related characteristics that were statistically significant at 12 months were peri- $\mathrm{PCl}$ complications ( $\mathrm{p} \leq 0.001$ ), use of GP $\mathrm{Ilb} / \mathrm{Illa}(\mathrm{p}=0.013)$, Tn-I elevation $>5 \times$ ULN $(p \leq 0.001)$, elevated CK-MB $(p=0.007)$, CK-MB elevation $>5 x$ ULN ( $p=0.012)$, Tn-I peak value $(p=0.05)$ and days of hospital stay $(p=0.002)$.

The multivariate analysis showed that the variables that were independently associated with a higher incidence of major cardiovascular adverse events were the presence of peri- $\mathrm{PCl}$ complications $(\mathrm{OR}=7.5$, $\mathrm{Cl}=1.25-45, \mathrm{p}=0.027)$ and troponin increase $>5 \mathrm{x}$ ULN (OR $=7.5, \mathrm{Cl}=1.25-45, \mathrm{p}=0.027)$.

\section{Discussion}

We present the results of a series of consecutive patients who underwent successful elective PCI. Only patients with stable coronary disease were included, since $\mathrm{Tn}-\mathrm{I}$ is a highly sensitive marker of myocardial 
Gaceta Médica de México. 2018;154

Table 3. Angiographic and procedure characteristics

\begin{tabular}{|c|c|c|c|c|c|c|c|c|}
\hline \multirow[t]{2}{*}{ Variable } & \multicolumn{6}{|c|}{ Mean \pm SD } & \multirow[b]{2}{*}{$\stackrel{\infty}{-}$} & \multirow[t]{2}{*}{$p$} \\
\hline & \multicolumn{2}{|c|}{ Total patients $(n=91)$} & \multicolumn{2}{|c|}{ Elevated Tn-I $(n=32)$} & \multicolumn{2}{|c|}{ Tn-I no elevada $(n=59)$} & & \\
\hline Compromised vessels & \multicolumn{2}{|c|}{$1.73 \pm 0.87$} & \multicolumn{2}{|c|}{$2.00 \pm 0.84$} & \multicolumn{2}{|c|}{$1.58 \pm 0.85$} & \multirow{4}{*}{\multicolumn{2}{|c|}{$\begin{array}{l}0.009 \\
0.028 \\
0.029 \\
0.633\end{array}$}} \\
\hline Treated vessels & & & & & & & & \\
\hline Stents placed & & & & & & & & \\
\hline \multirow[t]{2}{*}{ LVEF } & \multicolumn{2}{|c|}{$51.43 \pm 7.7$} & \multicolumn{2}{|c|}{$51.41 \pm 8.7$} & \multicolumn{2}{|c|}{$51.44 \pm 7.2$} & & \\
\hline & $\mathrm{n}$ & $\%$ & $\mathrm{n}$ & $\%$ & $\mathrm{n}$ & $\%$ & & \\
\hline Syntax $<22$ & 69 & 75.8 & 19 & 59.4 & 50 & 84.7 & $v$ & 0.007 \\
\hline Syntax 23-32 & 16 & 17.6 & 10 & 31.2 & 6 & 10.2 & & 0.012 \\
\hline Syntax > 33 & 6 & 6.6 & 3 & 9.4 & 3 & 5.1 & & 0.358 \\
\hline $\mathrm{PCl}$ with stent & 90 & 98.9 & 32 & 100 & 58 & 98.3 & 4 & 0.459 \\
\hline AHA/ACC B2/C PCI lesion & 63 & 69.2 & 24 & 75 & 39 & 66.1 & $\frac{\varsigma}{\circ}$ & 0.380 \\
\hline Bifurcation PCl & 19 & 20.9 & 11 & 34.4 & 8 & 13.6 & $=$ & 0.020 \\
\hline Multi-vessel PCl & 17 & 18.7 & 9 & 28.1 & 8 & 13.6 & & 0.089 \\
\hline GP ॥B/IIIA inhibitor & 9 & 9.9 & 5 & 15.6 & 4 & 6.8 & & 0.177 \\
\hline Procedure complications & 14 & 15.4 & 11 & 34.4 & 3 & 5.1 & 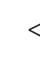 & 0.001 \\
\hline Dissection & 3 & 21.4 & 2 & 18.2 & 1 & 33.3 & $\frac{\text { 은 }}{2}$ & \\
\hline Secondary branch occlusion & 7 & 50 & 5 & 45.5 & 2 & 66.7 & $\frac{0}{\mp}$ & \\
\hline Acute thrombosis & 1 & 7.1 & 1 & 9.1 & 0 & 0 & $\stackrel{+}{5}$ & \\
\hline No reflow & 0 & 0 & 0 & 0 & 0 & 0 & $\frac{7}{3}$ & \\
\hline Perforation & 1 & 7.1 & 1 & 9.1 & 0 & 0 & 요다. & \\
\hline Sustained hypotension & 1 & 7.1 & 1 & 9.1 & 0 & 0 & $\frac{\partial}{0}$ & \\
\hline Vasospasm & 1 & 7.1 & 1 & 9.1 & 0 & 0 & 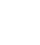 & \\
\hline
\end{tabular}

$\overline{\mathrm{ACC}}=$ American College of Cardiology, $\mathrm{AHA}=\mathrm{American}$ Heart Association, $\mathrm{CPK}-\mathrm{MB}=$ creatine phosphokinase, $\mathrm{GP}=$ glycoprotein, $\mathrm{LVEF}=$ left ventricular ejection fraction, $\mathrm{PCl}=$ percutaneous coronary intervention, Tn-I=troponin I.

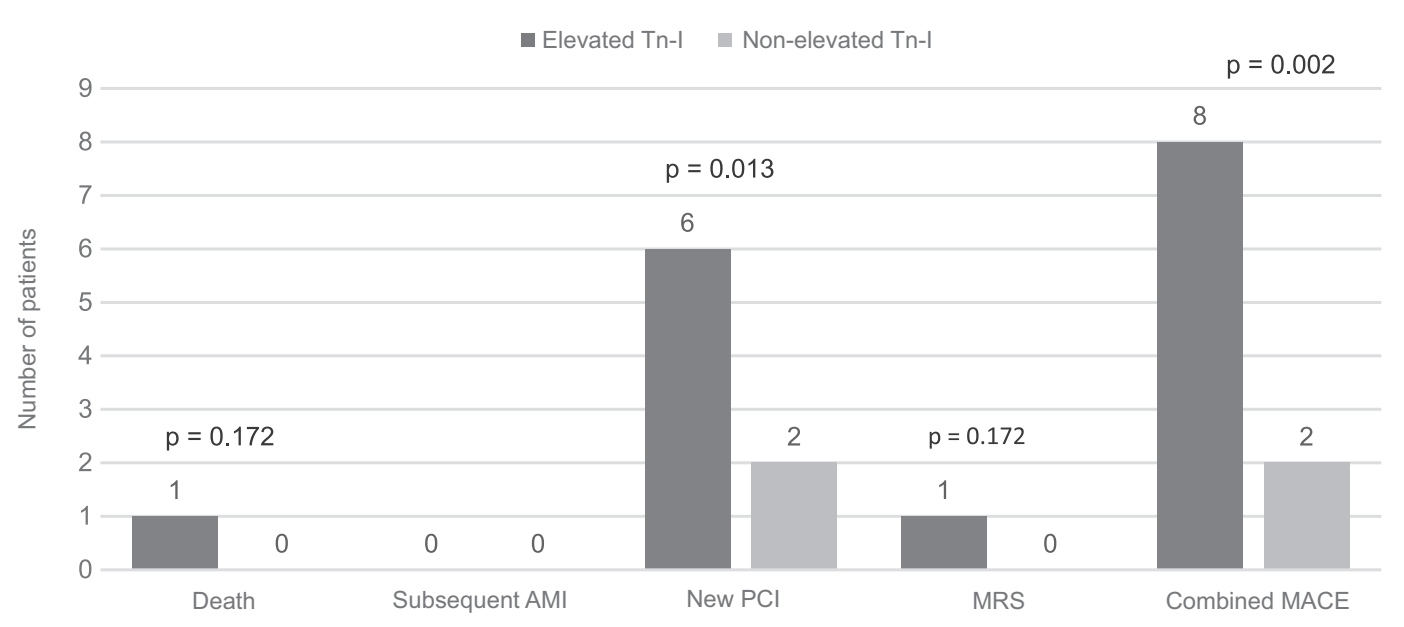

Figure 1. Cardiovascular adverse events at 12 months of follow-up in the groups with and without troponin I elevation. AMI = acute myocardial infarction, $\mathrm{PCl}=$ percutaneous coronary intervention, MRS = myocardial revascularization surgery, $T n-I=$ troponin I. 
damage that has prognostic value in patients admitted to the hospital with acute coronary syndrome.

The frequency of $\mathrm{Tn}-\mathrm{I}$ elevation in our study was $35.2 \%$, similar to Cavallini et al. ${ }^{9}$ and Ertan et al. ${ }^{16}$ previously reported figures, in studies where 39.4 and $34 \%$ of patients, respectively, showed post- $\mathrm{PCl} \mathrm{Tn}-\mathrm{I}$ levels increase. Other investigations have reported lower figures, such as a $13.2 \%$ prevalence observed by Zhang et al..,10 and others have reported a frequency as high as $44.2 \%$, as Claudio et al. did. ${ }^{5}$

There are several situations that have been associated with troponin elevation after elective $\mathrm{PCl}$. Factors related to the patient include multi-vessel disease, kidney failure, old age, intervention in de novo lesions, left ventricular ejection fraction decrease, intervention in saphenous vein grafts and in complex lesions. Factors related to the procedure have been reported, including: no-reflow phenomenon, insufflation prolonged time, vessel abrupt closure, sustained chest pain (> 5 minutes), long lesion ( $>20 \mathrm{~mm}$ ), distal embolization, thrombus formation, vessel dissection, hypotension, stent over-expansion and secondary branch occlusion. $9,11,16-20$

In our study, post- $\mathrm{PCl}$ elevation predictors were found to be intervention in bifurcation, elevated CPK-MB above ULN, 23 to 32 Syntax score, longer hospital stay, higher number of compromised and treated vessels, higher number of stents placed and higher statistical association with the development of peri-PCl complications (OR $=97, \mathrm{Cl}=2.4-38.5, \mathrm{p} \leq 0.001)$. These observations are consistent with previous studies that have implicated peri- $\mathrm{PCl}$ complications as the main mechanism responsible for the existence of myonecrosis. ${ }^{9}$

Nienhuis et al. demonstrated that patients with multiple-vessel angioplasty are more likely to have increased troponin levels and to experience cardiovascular events in comparison with patients with single-vessel angioplasty (31.5 versus $18.3 \%$ and 28 versus $19 \%$, respectively). ${ }^{21}$ In our study, multi-vessel disease was more common in patients with Tn-I elevation (28.1 versus $13.6 \%$ ), with the difference not being statistically significant $(p=0.089)$.

CPK and CPK-MB elevation after elective $\mathrm{PCl}$ has been associated in previous studies with an increase in the risk of death, acute myocardial infarction and repeated revascularization;22-24 however, other have not shown any relationship between elevation of these cardiac markers and survival. ${ }^{25-27}$

Currently, there is no consensus in the literature regarding the prognostic value of $\mathrm{Tn}-\mathrm{I}$ concentrations increase after elective $\mathrm{PCl}$. In a study carried out by
Mark et al., ${ }^{18}$ post-elective $\mathrm{PCI} \mathrm{Tn}-\mathrm{I}$ increase was shown to have a strong prognostic implication, whereas Ertan et al. ${ }^{16}$ concluded that $\mathrm{Tn}-\mathrm{I}$ elevation after successful $\mathrm{PCl}$ is not associated with late cardiac adverse events. Nienhuis et al. ${ }^{11}$ conducted a meta-analysis of 20 studies published from 1998 to 2007 that included 15581 patients. Troponin was found to be elevated in $32.9 \%$. During a mean follow-up of 16.3 months, an increase in mortality was found that was significantly associated with post- $\mathrm{PCl}$ troponin elevation (4.4 versus $3.3 \%, p=0.001, O R=1.35$ ). The combination of death and non-fatal myocardial infarction was also more common in the group with post- $\mathrm{PCl} \mathrm{Tn}-\mathrm{I}$ elevation (8.1 versus $5.2 \%, p<0.001, O R=1.59)$. The meta-analysis concluded that troponin elevation after elective $\mathrm{PCI}$ provides important prognostic information.

In our study, 10 patients (11\%) experienced major adverse cardiovascular events. Ricciarddi et at., ${ }^{20}$ during a mean follow-up of 444.6 days, demonstrated that $27 \%$ of patients experienced at least one major cardiac adverse event, which is a higher number in comparison than that observed in our sample. Overall mortality in our sample was low $(1.1 \%)$, similar to that reported by Nienhuis et al..$^{18}(1 \%)$. MACE predominant form was percutaneous coronary re-intervention $(8.8 \%)$, which is a similar finding to that in the study by Naghet et al., where after an 18-month follow-up, patients with post- $\mathrm{PCI} \mathrm{Tn}$-I elevation had a MACE rate of $25 \%$ (17.7\% owing to re-PCl). ${ }^{28}$

Pharmacological interventions that have anti-inflammatory and anti-thrombotic effects such as statins and GP Ilb/Illa inhibitors have demonstrated to reduce the incidence and magnitude of angiographic complications and, therefore, of myonecrosis. ${ }^{20,29.30}$. The use of GP Ilb/ Illa inhibitors can reduce microembolization by preventing the formation of thrombi before, during and after $\mathrm{PCl}$, and also has been shown to reduce $\mathrm{PCl}$ major ischemic complications by 35 to $56 \%$ in a broad spectrum of angiographic clinical and morphologic situations. ${ }^{16}$ In our study, GP IIb/llla inhibitors were used in 9 patients $(9.9 \%)$, and were more frequently used in patients with $\mathrm{Tn}$-I elevation (15.6 versus $6.8 \%$ ), with the difference not being statistically significant $(p=0.177)$; they were used mainly in patients who experienced angiographic complications, without better or worse prognosis associated with their use being observed.

\section{Study limitations}

Since the present study was observational, retrospective and was carried out in a single hospital center, is 
subject to important limitations inherent to its nature: limited number of patients and relatively short follow-up period. As in other previous studies, coronary angiography and $\mathrm{PCl}$ analyses were not performed in an independent central angiographic laboratory, and the description of those variables that are potentially relevant for prognosis, such as lesion morphology, coronary artery disease extent, procedure result and revascularization degree, were left at the operator's discretion.

\section{Conclusions}

According to the results obtained in the present study, we can conclude that, in our setting, Tn-I elevation in patients with stable coronary disease is associated with higher occurrence of major adverse cardiovascular events at one year. Tn-I elevation is more common in patients more extensive and complex coronary disease, as well as in those who develop peri-procedure complications, particularly secondary branches occlusion and coronary dissection. The frequency of Tn-I elevation in patients was similar to that observed in other reports.

Future studies are needed with imaging techniques, such as intravascular ultrasound and optical coherence tomography, in order to improve the understanding of the mechanisms responsible for the presence of post$\mathrm{PCl}$ myonecrosis, as well as prospective controlled studies with larger samples, with the final goal to confirm currently existing evidences and to develop new therapeutic strategies in order to improve the prognosis in these patients.

\section{References}

1. Sánchez-Barriga JJ. Comportamiento de la mortalidad por cardiopatía isquémica en México en el periodo 2000-2007. Gac Med Mex. 2009;145:375-382.

2. García-Castillo A, Jerjes-Sánchez $C$, Martínez-Bermúdez $P$, Azpiri-López R, Autrey-Caballero A, Martínez-Sánchez C, et al. RENASICA II. Registro Mexicano de Síndromes Coronarios Agudos. Arch Cardiol Mex. 2005;75:S6-S19.

3. Chávez-Domínguez R, Ramírez-Hernández JA, Casanova-Garcés JM La cardiopatía coronaria en México y su importancia clínica, epidemiológica y preventiva. Arch Cardiol Mex. 2003;73:105-114.

4. Murray CJ, López AD. Alternative projections of mortality and disability by cause 1990-2020: Global Burden of Disease Study. Lancet. 1997;349:1498-1504.

5. Cavallini C, Savonitto S, Violini R, Arraiz G, Plebani M, Olivari Z, et al. Impact of the elevation of biochemical markers of myocardial damage on long-term mortality after percutaneous coronary intervention: results of the CK-MB and PCl study. Eur Heart J. 2005;26:1494-1498.

6. Michaels AD, Chatterjee K. angioplasty versus bypass surgery for coronary artery disease. Circulation. 2002;106:e187-e190.

7. De-Labriolle A, Lemesle G, Bonello L, Syed AI, Collins SD, Ben-Dor I, et al. Prognostic significance of small troponin I rise after a successful elective percutaneous coronary intervention of a native artery. Am J Cardiol. 2009;103:639-645.

8. Bertinchant JP, Polge A, Ledermann B, Genet L, Fabbro-Peray P, Raczka $F$, et al. relation of minor cardiac troponin I elevation to late cardiac events after uncomplicated elective successful percutaneous transluminal coronary angioplasty for angina pectoris. Am J Cardiol. 1999;84:51-57.
9. Cavallini C, Verdecchia P, Savonitto S, Arraiz G, Violini R, Olivari Z, et al. Prognostic value of isolated troponin I elevation after percutaneous coronary intervention. Circ Cardiovasc Interv. 2010;3:431-435.

10. Zhang M, He H, Wang ZM, Xu Z, Zhou N, Chen B, et al. Diagnostic and prognostic value of minor elevated cardiac troponin levels for percutaneous coronary intervention-related myocardial injury: a prospective, single-center and double-blind study. J Biomed Res. 2014;28:98-107.

11. Nienhuis MB, Ottervanger JP, Bilo HJ, Dikkeschei BD, Zijlstra F. Prognostic value of troponin after elective percutaneous coronary intervention: a meta-analysis. Catheter Cardiovas Interv. 2008;71:318-324.

12. Selvanayagam JB, Porto I, Channon K, Petersen SE, Francis JM, Neubauer S, et al. Troponin elevation after percutaneous coronary intervention directly represents the extent of irreversible myocardial injury: insights from cardiovascular magnetic resonance imaging. Circulation. 2005; $111: 1027-1032$.

13. Ricciardi MJ, Wu E, Davidson C, Choi K, Klocke F, Bonow R, et al. Visualization of discrete microinfarction after percutaneous coronary interventions associated with mild creatine kinase-MB elevation. Circulation. 2001:103:2780-2783.

14. Mehran R, Dangas G, Mintz GS, Lansky AJ, Pichard AD, Satler LF, et al. Atherosclerotic plaque burden and CK-MB enzyme elevation after coronary interventions: intravascular ultrasound study of 2256 patients. Circulation. 2000;101:604-610.

15. Gómez-Hospital JA, Cequier A, Valero J, González-Costello J, Mañas P, Pascual $\mathrm{M}$, et al. El daño miocárdico mínimo durante el intervencionismo coronario percutáneo no influye en el pronóstico a largo plazo. Rev Esp Cardiol. 2009;62:625-632.

16. Okmen E, Cam E, Sanli A, Unal S, Tartan Z, Vural M. Cardiac troponin I increase after successful percutaneous coronary angiopiasty: predictors and long-term prognostic value. Angiology. 2006;57(2):161-169.

17. Thygesen K, Alpert JS, Jaffe AS, Simoons ML, Chaitman BR, White HD, et al. Third universal definition of myocardial infarction. Eur Heart $\mathrm{J}$. 2012;33:2551-2567.

18. Nienhuis MB, Ottervanger JP, Dikkeschei B, Suryapranata $H$, De-Boer MJ, Dambrink JH, et al. Prognostic importance of troponin $\mathrm{T}$ and creatine kinase after elective angioplasty. Int J Cardiol. 2007:120: 242-247.

19. Miller WL, Garratt KN, Burritt MF, Lennon RJ, Reeder GS, Jaffe AS. Baseline troponin level: key to understanding the importance of post- $\mathrm{PCl}$ troponin elevations. Eur Heart J. 2006;27:1061-1069.

20. Ricciardi MJ, Davidson CJ, Gubernikoff G, Beohar N, Eckman LJ, Parker MA, et al. Troponin I elevation and cardiac events after percutaneous coronary intervention. Am Heart J. 2003:145:522-528.

21. Nienhuis MB, Ottervanger JP, Dambrink JH, Dikkeschei LD, Suryapranata $\mathrm{H}$, Hoorntje $\mathrm{JC}$, et al. Troponin $\mathrm{T}$ elevation and prognosis after multivessel compared with single-vessel elective percutaneous coronary intervention. Neth Heart J. 2007;15:178-183.

22. Califf RM, Abdelmequid AE, Kuntz RE, Pompa JJ, Davidson CJ, Cohen EA, et al. Myonecrosis after revascularization procedures. J Am Coll Cardiol. 1998:31:241-251.

23. Tardiff BE, Califf RM, Tcheng JE, Lincoff AM, Sigmon KN, Harrington RA, et al. Clinical outcomes after detection of elevated cardiac enzymes in patients undergoing percutaneous intervention. IMPACT-II Investigators. Integrilin (eptifibatide) to Minimize Platelet Aggregation and Coronary Thrombosis-II. J Am Coll Cardiol. 1999;33:88-96.

24. Simoons $M L$, Van-Den-Brand $M$, Lincoff $M$, Harrington $M$, Van-Der-Wieken $\mathrm{R}$, Vahanian A, et al. Minimal myocardial damage during coronary intervention is associated with impaired outcome. Eur Heart J. 1999;20:1112-1119.

25. Klein LW, Kramer BL, Howard E, Lesch M. Incidence and clinical significance of transient creatine kinase elevations and the diagnosis of non-Q wave myocardial infarction associated with coronary angioplasty. J Am Coll Cardiol. 1991;17:621-626.

26. Kugelmass AD, Cohen CJ, Moscucci M, Piana RN, Senerchia C, Kuntz RE, et al. Elevation of creatine kinase myocardial isoform following otherwise successful directional coronary atherectomy and stenting. Am J Cardiol. 1994:74:748-754.

27. Kini A, Marmur JD, Kini S, Dangas G, Cocke T, Wallenstein S, et al. Creatine kinase-MB elevation after coronary intervention correlates with diffuse atherosclerosis, and low-to-medium level elevation has a benign clinical course: implications for early discharge after coronary intervention. J Am Coll Cardiol. 1999;34:663-671.

28. Nageh T, Sherwood RA, Harris BM, Thomas MR. Prognostic role of cardiac troponin I after percutaneous coronary intervention in stable coronary disease. Heart. 2005;91:1181-1185.

29. Pasceri V, Patti G, Nusca A, Pristipino C, Richichi G, Di-Sciasció G, et al. Randomized trial of atorvastatin for reduction of myocardial damage during coronary intervention: results from the ARMYDA (Atorvastatin for Reduction of Myocardial Damage During Angioplasty) study. Circulation. 2004:110:674-678.

30. EPISTENT Investigators. Randomized placebo-controlled and balloon-angioplasty-controlled trial to assess safety of coronary stenting with use of platelet glycoprotein-IIb/IIla blockade. Lancet. 1998;352: 